\begin{tabular}{l|l}
$\mathbf{m}$ & south \\
$\mathbf{m} \boldsymbol{n}$ & asia
\end{tabular}

samaj multidisciplinary

ui,u academic
South Asia Multidisciplinary Academic Journal

17| 2018

Through the Lens of the Law: Court Cases and Social Issues in India

\title{
Public Hearings as Social Performance: Addressing the Courts, Restoring Citizenship
}

Stéphanie Tawa Lama-Rewal

\section{CpenEdition}

\section{Journals}

Electronic version

URL: http://journals.openedition.org/samaj/4413

DOI: $10.4000 /$ samaj.4413

ISSN: $1960-6060$

Publisher

Association pour la recherche sur l'Asie du Sud (ARAS)

Electronic reference

Stéphanie Tawa Lama-Rewal, « Public Hearings as Social Performance: Addressing the Courts, Restoring Citizenship », South Asia Multidisciplinary Academic Journal [Online], 17 | 2018, Online since 18 September 2017, connection on 20 April 2019. URL : http://journals.openedition.org/samaj/4413 DOI : 10.4000/samaj.4413

This text was automatically generated on 20 April 2019

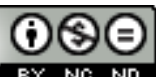

This work is licensed under a Creative Commons Attribution-NonCommercial-NoDerivatives 4.0 International License. 


\title{
Public Hearings as Social Performance: Addressing the Courts, Restoring Citizenship
}

\author{
Stéphanie Tawa Lama-Rewal
}

1 The relationship of the judiciary with politics has often been thematized as "judicial activism." ${ }^{1}$ In the Indian context this notion emerged in the public debate in the late 1970s, when a new procedure, the Public Interest Litigation (PIL), allowed

the court (to reinterpret) the provisions of the fundamental rights more liberally so as to maximize the rights of the people, particularly the disadvantaged sections of society, and facilitated access to the courts by relaxing its technical rules of locus standi, and other procedural/institutional innovations (Sen 2012b:8).

What has been called the increasing "legalism" of the Indian Left (Sircar 2012) is a phenomenon that is closely linked, in a symmetrical way, to this brand of judicial activism $^{2}$ : collective action increasingly appropriates, even as it transforms it, the language of the judicial process. Thus since the late 1990s, major claims addressed to the state by, or on behalf of, the underprivileged, have been formulated in terms of rights, such as the right to work, to food, to healthcare etc. One observes, as Sundar puts it, "a more rights-based refashioning of the public sphere from below" (Sundar 2011:177). Collective action increasingly addresses the courts, as much as governments or legislative assemblies.

2 This paper aims to show, through an analysis of public hearings (or jan sunwai [hearing of the people] in Hindi), that the "legalism" of Indian progressive social movements is at work not only in the language, but also in the form of mobilizations. Over the past two decades, public hearings have become a common mode of collective action. They can be provisionally described as public meetings that organize a confrontation, moderated by a group of experts, ${ }^{3}$ between the (supposed) beneficiaries of a given public policy or scheme, and the authorities in charge of implementing said policy/scheme. From the first jan sunwai organized in the mid-1990s by the Rajasthan-based Mazdoor Kisan Shakti Sangathan ("Workers' and Farmers' Power Organisation," MKSS) to the proliferation of public hearings around various causes and for various publics ${ }^{4}$ today, the procedure has 
somewhat evolved, as we will see. It is often the most visible part of a larger process, which can be a social audit, a consultation, or a campaign on a given issue. While these larger processes, in all their complexity and variety, must be kept in mind, the unique visibility of public hearings gives them a crucial importance in the mobilization, and justifies analyzing them as a special moment.

3 This particular, relatively new form of collective action, I argue, reveals the complex, ambivalent relationship between civil society organizations ${ }^{5}$ (CSOs) and the courts. My analysis will partly draw from the perspective of cultural pragmatics insofar as it will consider public hearings as a "social performance" (Alexander 2004), that is, a highly symbolic type of social event-an event whose significance can be understood only if one pays utmost attention to the various layers of meaning that are produced by its mise-enscène, actors and scripts.

4 The first part of the paper will contextualize and describe public hearings in their different variants. Thus Section One will briefly situate the emergence and multiplication of public hearings since the 1990s, with a focus on the crucial role played by the National Campaign for People's Right to Information; Section Two will distinguish four main types of public hearings, and narrate the unfolding of one of them.

5 The second part of the paper is more interpretive in nature: it endeavors to understand public hearings as social performance through an examination of their affinities with three established dispositives ${ }^{6}$ : the PIL; community meetings; and Truth commissions. Thus Sections Three and Four aim to demonstrate the essential hybridity of public hearings as a form, half-way between the courts and the streets, or more precisely, between the PIL and the community meeting. In Section Three I will highlight the strong continuity between public hearings and the PIL (at least as it was defined in the first decade of its existence) both in their rationale and in their procedure. In Section Four, by contrast, I will underline the affinities of public hearings with community meetings. Finally in Section Five, I will argue that the hybrid nature of public hearings strongly evokes the Truth commissions that have been set up in many countries in the past decades, and I will reflect on their capacity to offer, like these commissions, a form of restorative justice.

6 This paper is based on fieldwork carried out in Delhi between 2004 and 2014. I conducted a series of 33 semi-directed interviews with organizers (who were members of CSOs, political parties, trade unions...) and participants in public hearings. I was able to directly observe three public hearings in Delhi, but since such events are often video-recorded, I was able to watch the unfolding of many more, organized on various issues, by various types of organizations, in Delhi, Rajasthan and Karnataka-these videos indeed proved to be a very rich research material, even though they give access to the public, final part of the public hearing only, and not to the extensive preparatory work that precedes it. Finally the reports often produced by facilitating organizations, as well as the media, constituted another important source of information.

\section{A defining moment: the National Campaign for People's Right to Information (1996-2005)}

7 Public hearings came into the public eye in the 1990s, and seem to have multiplied in the 2000s. The notion of jan sunwai did exist before the 1990s in the Indian repertoire of 
collective action, but its meaning was quite vague. It was the MKSS, a civil society organization created in Rajasthan in 1990 and defining itself as a "people's organization" (Mazdoor Kisan Shakti Sangathan 2017), which gave it a new meaning and relevance. The MKSS held its first jan sunwai in 1994, in the context of its struggle for the implementation of minimum wage legislation. To put it very briefly, this struggle made activists realize the magnitude of corruption in the management of public work contracts; they understood that such corruption could not be fought unless people had access to public records. ${ }^{7}$ They decided to focus on the right to information (RTI), i.e. the right for all citizens to have access to public documents. The National Campaign for People's Right to Information (NCPRI) was led by the MKSS from 1996 onwards, but it brought together a vast coalition of organizations and individuals (Jenkins and Goetz 1999). In the course of this campaign, the MKSS reinvented the jan sunwai by evolving a methodology that is used by many CSOs today (and that I will describe later).

8 The NCPRI played a key role in the development of public hearings for two main reasons. Firstly, the right to information is essential to the power of public hearings as a form of collective action. It gives access to official documents, which offers a precise view of official decision-making processes. The RTI, therefore, makes it possible for lay people to check, verify, monitor the action of state authorities-be it a village sarpanch [elected leader], the Education department of a state government, or the National Human Rights Commission, to take only a few examples. The right to information makes it possible for citizens to confront bureaucrats because it arms them with documents that are produced by bureaucrats, and whose validity, therefore, cannot be refuted.

9 Secondly, the campaign itself proved to be a huge success: a Right to Information Act was adopted in Rajasthan in 2000, then in several other states, and at the Union level in 2005. The NCPRI's capacity to coalesce a large variety of organizations and movements, and the fact that it resulted in the adoption, at the national level, of a legislation that is reputed to be one of the most empowering in the world, turned the Campaign into a hallmark of the deepening of India's democracy. The NCPRI played a crucial role in popularizing the jan sunwai through its careful communication emphasizing the usability and effectiveness of the RTI (Webb 2010). In spite of initial difficulties in replicating the jan sunwai methodology (Jenkins and Goetz 1999:610, 619), which is very demanding in terms of human resources and commitment, many organizations that were involved in the NCPRI acquired a training, either formally of informally, in organizing a jan sunwai, and later used this training in their action on various issues-be it access to schools, subsidized food or health care. Thus the NCPRI's success made the jan sunwai appear as a powerful mode of mobilization, which encouraged civil society organizations to adopt it.

10 The Right to Information Act was only one among a series of pro-poor legislations that marked the first government led by the United Progressive Alliance (2004-2009). While a discussion of the reasons, forms and limitations of this pro-poor phase is beyond the scope of this paper, it must be noted that a series of welfare policies adopted from 2005 onwards have made social audits-of which public hearings are an important partmandatory. There is no coincidence here. Leaders and associates of the MKSS such as Aruna Roy, Jean Dreze or Kiran Bhatty have played an important role in drafting the National Rural Employment Guarantee Act (NREGA, a food for work program adopted in 2005), the Right of Children to Free and Compulsory Education Act (adopted in 2009) or the Food Security Act (adopted in 2013), be it as members of the National Advisory Council $^{8}$ or otherwise. ${ }^{9}$ 
11 Today one hears of public hearings in many states, in rural areas as well as in metropolises, around a large variety of issues (Iqbal 2015), such as work, education (Anon 2011), food (The Hindu 2010), healthcare (Byatnal 2012), pensions for the elderly (Shivakumar 2014), but also atrocities against Dalits (The Hindu 2005) or the rights of sexual minorities (Chowdhury 2011). The procedure has somewhat morphed as it became more popular, therefore it seems necessary now to offer a more precise view of what a public hearing is-or can be.

\section{Four types of public hearings}

12 A public hearing can indeed be many different things: from a marketing technique to an administrative procedure, to a mode of political mobilization. In the contemporary Indian context, different kinds of meetings come under this single appellation. In order to avoid confusion, I will distinguish four main types of public hearings on the basis of four criteria, as shown in Table 1:

Table 1. A basic typology of public hearings

\begin{tabular}{|c|c|c|c|c|}
\hline & Organizers & Objectives & $\begin{array}{l}\text { Nature of the } \\
\text { meeting }\end{array}$ & $\begin{array}{l}\text { Presence of state } \\
\text { authorities }\end{array}$ \\
\hline Jan sunwai & $\begin{array}{l}\text { CSOs } \\
* * * * * * * * * \\
\text { State } \\
\text { authorities } \\
+ \text { CSOs }\end{array}$ & $\begin{array}{l}\text { Implementation of an } \\
\text { existing policy/law }\end{array}$ & Confrontation & $\begin{array}{l}\text { Yes, especially if } \\
\text { the state is co- } \\
\text { organizer }\end{array}$ \\
\hline Jan sunwai "light" & $\begin{array}{l}\text { CSOs/ } \\
\text { political } \\
\text { parties }\end{array}$ & Grievance redressal & Expression & No \\
\hline People's tribunal & $\mathrm{CSOs}$ & $\begin{array}{l}\text { Reform of an existing } \\
\text { policy/law }\end{array}$ & $\begin{array}{l}\text { Expression of } \\
\text { demands }\end{array}$ & Not mandatory \\
\hline $\begin{array}{l}\text { Environmental } \\
\text { public hearing }\end{array}$ & $\begin{array}{l}\text { State } \\
\text { authorities }\end{array}$ & $\begin{array}{l}\text { Implementation of a } \\
\text { project }\end{array}$ & Consultation & Yes \\
\hline
\end{tabular}

This table, for the sake of clarity, highlights the differences between the various types of public hearing. In reality there are many overlaps, especially regarding their objectives and nature: thus all public hearings aim at some kind of awareness raising, in addition to the objectives mentioned here; and all involve some expression from the audience. 
18 Let us now look more closely at these four types of public hearings. Firstly, the jan sunwai could be described in the following manner: this is a public meeting lasting from half a day to three days, organized around an issue related to a public policy, and which consequently involves state authorities. To give an example: "Delhi Forces," a network of civil society organizations working in the Indian capital city, organized in 2010-11 a series of three jan sunwais on the issue of "Health, education, nutrition, safety and care of women and children in urban poor settlements of Delhi." The policy at stake was the national policy regarding the care of young children in poor urban settlements (i.e. slums), a policy that takes the shape of a series of schemes, most notably the Integrated Child Development Services (ICDS). Concerned state authorities included the Health, Education and Sanitation departments of the Municipal Corporation of Delhi; the Health and Women and Child Development departments of the Government of the National Capital Territory of Delhi; and the Delhi Jal Board (a para-statal agency in charge of water).

19 A jan sunwai typically involves three main types of participants: (i) the audience, that is the local people (the jan), from among whom a number of aggrieved persons will narrate their story; (ii) the jury or panel, consisting of half a dozen experts, including retired judges, retired bureaucrats, lawyers, academics, journalists, senior activists; (iii) representatives of state authorities, that is, a few (often junior) administrative officers. The largest group of participants is made up of the direct victims of the (nonimplementation of the) policies at stake, with their relatives and neighbors. Thus in the Delhi Forces' public hearings mentioned above, participants were the parents or grandparents of children who could not go to school because they had to take care of their younger siblings for want of child care in the area; of children who kept being ill because sanitation work was not carried out; of handicapped children that no government school wanted to enroll; etc.

20 A jan sunwai is not an isolated event; it is the emerging, visible part of a larger process, both before and after the D-day, which requires substantial work by organizers, who may be one or several civil society organizations (or more rarely, a political party); also, in some cases the organizers will be supported by a state authority. This process typically starts about three months prior to the day of the public hearing: organizers, on the basis of their ongoing work with local communities, are aware of a given problem-for example, the denial of healthcare to slum dwellers in Delhi. They will select a series of cases that they see as emblematic of the different aspects of the problem. In our example they selected cases of denial of healthcare by public and private facilities; at the primary, secondary and tertiary levels; with various types of consequences etc. A factsheet will be prepared for each case, with all relevant information (details about the aggrieved family, about the wrongdoings/malpractices, about the status of the police file, if any). Victims will also be prepared for the hearing: organizers will explain the whole process to them, its objectives, what can be expected of it, and the specific role that their testimony will play in it; they will help these people get ready to speak in public about their ordeal on the day of the jan sunwai, within the allotted time (usually 5 to 10 minutes). Simultaneously, organizers will put together a jury or panel. They will invite administrative officers of the concerned departments. Finally, they will organize the logistics of the meeting.

21 On D-day, organizers will introduce the meeting and facilitate interactions between the testifiers, the jury and the administrative officers. Aggrieved persons will briefly narrate 
their story in front of the jury, the administrative officers and the audience. Jury members will occasionally question the testifier or one of the administrative officers present; at the end of the meeting, they will give a series of recommendations. They will also write a report that organizers will send to the relevant authorities and to the media so that action be taken. Last but not least, organizers will follow up on the reception and impact of the report.

Some jan sunwais are part of an officially mandated social audit, that is, an audit of social policies conducted by the people themselves, as provided by recent policies such as NREGA, the Right to Education Act or the Food Security Act. In this case, state authorities will be participants on both sides of the fence. For instance a series of jan sunwais have been organized by the National Commission for Protection of Child Rights (NCPCR), charged with monitoring the implementation of the Right to Education Act. In these jan sunwais one arm of the state has confronted another arm: typically, NCPCR members have held to account members of the Education department of the concerned state and municipal governments.

The second type of public hearings call themselves "jan sunwais" even though they significantly differ from the typical jan sunwais described above-this is why I call them “jan sunwai light." For instance in August 2011, a group of Delhi Resident Welfare Associations organized a "jan sunwai" on the issue of the increasing costs of electricity. This second type of public hearing essentially targets the local community with whom organizers have been working. It is meant as a tool for awareness raising and the primary focus is on the public expression, by victims, of their grievances. These meetings tend to be isolated events: the documentation work done prior to the D-day, as well as the followup, is much less thorough than for real jan sunwais. Representatives of state authorities are rarely present; indeed they are not always invited. Such meetings are a weak, diluted, less demanding form of jan sunwai, insofar as they forego the structural and confrontational dimensions that define the latter.

What about People's tribunals? ${ }^{10}$ In the Indian context this is an ambiguous category, since a people's tribunal can be a type of public hearing; or a more or less permanent structure that organizes public hearings; or both. Thus an "Independent People's Tribunal," composed of retired judges and lawyers was set up in 1993 to look at environmental and human rights violations; in January 2014 it organized an "Independent People's Tribunal on the Functioning of the National Human Rights Commission in India" in a university in Delhi. People's tribunals are a grander variant of public hearings, which depart from the jan sunwai in two main ways. One, they are a more formalized, higher level structure: they exist most often at the state or national level, whereas jan sunwais may take place at the level of a village, a city or a city area. Two, as a consequence of this difference in scale, the audience of people's tribunals is not made up of the local people, but mostly of CSOs who represent those people they have been working with. Thus activists will form a large part of the audience; sometimes they will present cases on behalf of the actual aggrieved persons; and of course senior activists will be members of the jury/panel.

Finally public hearings can also be a very official procedure that, since 1997, has becomemandatory in the framework of the "Environmental Impact Assessment Notification" process set up for every major industrial or infrastructural project. Public hearings organized in that particular context are a formalized type of consultation which is part of a set of regulations. Since it is "the only open space in the regulatory decision- 
making process" (Kohli and Menon 2012:22) regarding environment protection, environmental activists try to use it as a "platform of contestation." ${ }^{11}$ The battle is a tough one however, for public hearings organized in this specific context are "repeatedly emerging as sites for chicanery" (Sundar 2011:183). ${ }^{12}$

While this fourth type of public hearing is clearly beyond the scope of this paper, the following analysis will deal with the first three types. I will henceforth speak of "public hearings" whenever the argument applies to jan sunwais, "jan sunwais light" and people's tribunals; and when it does not, I will specify which type of public hearing I am referring to.

\section{Addressing the courts}

Public hearings are essentially concerned with rights and their denial-that is, with justice in a substantive sense but also, as I will show, in a procedural sense. Indeed analyzing public hearings as a social performance makes it clear that they address the judiciary, that is, the courts, in three different but related ways: they work to some extent like the courts; they work with the courts-especially when courts deal with PIL-but they also work against the courts.

On a first level of analysis, it appears that public hearings imitate or mimic the courts to some extent; this comes out clearly through the language and intellectual references that they use, their actors, their stated objectives, and even their spatial arrangement. To start with, they use a vocabulary that clearly draws from the universe of the judiciary. Some organizers of public hearings also call them jan adalat [people's court] in Hindi, or "civil court" in English. The very notions of "hearing" or "tribunal," of course, evoke a judiciary process. Moreover, as mentioned before, the stories narrated by aggrieved persons during the hearing are called "cases," sometimes "testimonies"; these people are often called "victims"; and the group of eminent persons who listens to them throughout the hearing is called a "jury" as often as a "panel."

Among the members of the jury/panel, retired judges and lawyers-that is, specialists of the law-play a special role. These professionals-turned/cum-activists are crucial to the credibility and impact of the hearing. While their professional expertise is indispensable to draft the report that must come out of the public hearing, it is also extremely useful to facilitate the circulation of the report among active judges, as explained by an organizer:

The report of the jury helps us a lot in our legal advocacy, for the mere fact that if a retired High court or Supreme Court judge is saying something, the existing judiciary always will take it into consideration. ${ }^{13}$

Moreover public hearings make constant references to a series of texts that are normative in nature-be it national or state policies, the Constitution, Supreme Court judgments, international covenants to which India is a signatory, etc. Indeed these legal documents are a major reference in the jury's recommendations.

The spatial organization of public hearings itself evokes that of a court ${ }^{14}$ : the jury often sits on a dais; and aggrieved persons will stand next to the jury, facing the audience, while they narrate their case. Foucault remarked, in a conversation with Maoist activists about the notion of "popular justice," that the spatial arrangement of a meeting is not neutral but "implies an ideology" (Foucault 1980:8). Indeed the spatial arrangement of public hearings, when combined with the norms to which they refer, the presence of retired judges and lawyers, and their legalistic vocabulary, produces a whole dispositive 
that, by imitating a court of law, upholds the courts' value and relevance as a site for the public expression of truth and the redress of grievances-in short the quest for justice.

Two more features support the idea that public hearings replicate the courts-if one considers the functioning of the courts that is specific to PIL cases: the absence of an adversarial procedure, and the role of a documentation phase prior to the hearing.

Public hearings do not pursue cross examination: the analysis of each case presented to the jury is obviously partial. Testifiers might occasionally be questioned by the jury on some details of the case, or the jury might seek clarifications on the part of the representatives of state authorities if they are present; but cases will usually have been selected and documented by organizers so as to highlight blatant wrongdoing on the part of authorities..$^{15}$ The preparatory work devoted to the documentation and selection of cases, contributing to the report that will be used by the jury on D-day, is therefore crucial. This involves a long process, described as follows by a member of a CSO that coorganized a public hearing on the implementation of the Right to Education Act in Delhi in 2011:

We organized different strategies, like we had small meetings with the community where we met the people, 20 to 25 persons, and we had very big meetings like 200 to 300 people. At the meetings we shared information that we had been collecting in different ways, via lots of RTI applications, and we visited the schools and got lots of information from there, we even had a focus-group discussion with the parents to collect information from parents' knowledge on how schools are functioning there; then we had discussions with children groups, with students going to these particular schools... The particular work for the jan sunwai was from January till April, but before that we had started creating the environment for the jan sunwai, we started preparing the community, informing them about the wants of the system, we asked them to file complaints against that system: if there is no water facility in a government school, then we inform parents about the budget that comes to the school for water facilities; if the system is not so good in schools, we motivate them to file a complaint, because we feel that we should have very solid data with us about the lack of facilities, because jan sunwai is a tool that will address these gaps in the system... During this process we identified the cases, 804 complaints were filed during the whole process, out of those we chose 30 cases, we broke it up under the thematic areas of the RTE act, like infrastructure, collection of fees, negligence, quality of education, in these thematic areas we tried to find strong cases ... ${ }^{16}$

These two features of the process-the absence of an adversarial procedure, and the phase of documentation-are precisely specific to the PIL procedure, as explained by Sarbani Sen:

The court felt that in cases where one of the parties were members of disadvantaged communities, [the usual] procedural rules could lead to injustice because of the difficulty in getting competent legal representation and inability to produce evidence before the court. Therefore, when disadvantaged members of the "public" came before the court for enforcement of their fundamental rights, it was necessary to evolve a new procedure to make it possible for such litigants to produce the necessary material before the court... This judicial conviction led to the court appointing commissions for gathering facts and data in regard to a complaint of a breach of a fundamental right. The report of the commissioner would furnish prima facie evidence of the facts and data gathered by the commissioner (Sen 2012a:5).

These procedural affinities have much to do with the fact that PIL (at least in the first decade of their existence) and public hearings largely share the same public-a public 
characterized by marginalization and vulnerability. This comes out clearly in this statement of Justice Bhagwati, one of the chief promoters of the PIL:

Public interest litigation, as we conceive it, is essentially a cooperative or collaborative effort ... to secure observance of the constitutional or legal rights, benefits and privileges conferred upon the vulnerable sections of the community and to reach social justice to them (cited in Sen 2012b:10).

This statement also reveals the centrality of the notion of accountability, in the PIL as in public hearings. Indeed

the court has, through the adjustments and adaptations made through its PIL decisions ... created an "accountability" function that can be said to have altered accountability norms and administrative structures through the creation of new remedial action (Sen 2012 a:18).

Such proximity, both in procedural and in substantive terms, between PIL and public hearings, results from a process of reciprocal influence between the judiciary and social movements in the 1980s. On the one hand, "the interplay of the legal system and social movements led to creative adaptations of the legal process by the court" (Sen 2012b:9), that is the PIL. Conversely, PIL "[gave] the court a vibrancy and a relevance among social actors beyond the rarefied confines of the legal community" (Ramanathan 2002).

The relationship between public hearings and the courts is not only a symbolic one; it also consists of material connections. I have already mentioned that former judges and lawyers play a prominent role in the juries of public hearings; conversely, in the context of some PIL, the Supreme Court "appointed social activists or researchers as court commissioners to visit particular locations for fact-finding and to submit a quick but detailed report"(Sen 2012a:10).

Another important manner through which public hearings become relevant in the courts is by their own documentation work. This work is of prime importance as far as people's tribunals are concerned: "Tribunals are considered to be different from courts and other judicial bodies. They are meant to play the role of the expert in an area where judicial remedy is being sought," write Kohli and Menon (2012). Even though this statement was made in the context of a discussion of the National Green Tribunal, established by law in 2010 to deal with environment protection, it does apply to less official bodies such as the Independent People's Tribunal. Indeed, even reports coming out of a jan sunwai can beand have been-used to initiate a PIL. Judges are under no obligation, of course, to take into consideration the detailed, precisely documented reports that come out of some public hearings. But they have done it on several occasions.

Finally, even though public hearings have no legal value, my observations suggest that one of their major objectives-albeit one that is most often kept implicit, lest organizers be accused of interfering with the due process of law-is to put pressure on the courts by attracting public attention and shaping public opinion on the issue at stake, via the media. This is why the media are one of the main targets of public hearings: juries often include a journalist; the press is always invited to attend the hearing; and the report that comes out of the hearing is always sent to the press; in some cases it is even presented at a press conference. ${ }^{17}$ All these are ways to put pressure on active judges in an indirect, but by no means ineffective, fashion. ${ }^{18}$

Public hearings work, to some extent, like the courts and with the courts. But they also work against the courts insofar as they depart from actual judiciary practices in several blatant ways. Indeed the typical unfolding of a trial as described by Berti is the opposite of a public hearing: 
interactions take place within a small group of people gathered together in front of the judge. Verbal interactions ... are not always likely to be heard by those in attendance... The absence of a jury lessens the importance of performing the dialogue in ways that impress or emotionally affect a juror's opinion, allowing the judge, the prosecutor and the lawyers to discuss very technical points.... The witnesses ... are unable to follow negotiations of this kind (Berti 2011).

Such a description highlights how public hearings, beyond their procedural affinities with the judicial process (especially with the PIL), remain a very different, indeed an invented kind of court. As a dispositive, they suggest what courts could, or should be like; in other words they carry a critique of the courts that can be more or less implicit. "Beyond individual cases, public hearing is a tool, a vehicle, to show the outside world, to show the state forces that are supposed to implement this [Scheduled Caste and Scheduled Tribes (Prevention of Atrocities)] Act that they have failed," declared a well-known Dalit activist in his introduction to a public hearing on atrocities against Dalits (Bangalore, July 2006). "Clearly the holding of a [people's] tribunal is not a negation of the court, it is a shaming of the court; you're raising questions to the model of justice, but you don't pretend that you have a parallel justice" said another activist. ${ }^{19}$

Public hearings thus talk to the courts as much as they talk about the courts. They really address the courts in three different ways, three different senses: by imitating the courts, they uphold the central value of the judiciary as a site for the quest of justice; by being a different type of court, they criticize the judiciary and question its fairness; in these two ways, public hearings constitute a distorting mirror of justice. But in a less oblique way, public hearings work as a mode of advocacy which targets the judiciary along with other institutions such as state bureaucracies.

\section{Addressing the community}

Having shown how public hearings address the courts, or more generally the judiciary, I would also like to emphasize their proximity to street activism. Public hearings have many common points with community meetings, which is not surprising considering that such meetings are a basic form of action for most CSOs. More specifically, common elements include (i) the presence and role of forms of popular culture (songs, dances etc.); and (ii) a didactic dimension, geared towards raising awareness.

Public hearings often begin and end with a song; dances, skits or short videos are also used, mostly at the beginning. These elements of popular culture play an important communication role in the unfolding of the public hearing, with two main functions. The most prevalent function is one of critique: the song/dance/skit/video offers a critical definition of the issue at stake (the focus can be corruption; incompetence; caste prejudices etc.), often in a humoristic, ironic mode. Humor is particularly valuable because it helps undermine the difference of socio-economic status between the various types of participants, and therefore to facilitate the expression of those placed on the lower levels of social hierarchy. ${ }^{20}$

A second function is that of celebration-of the community, ${ }^{21}$ its strength, its solidarity etc. For instance a dance at the beginning of a public hearing on atrocities against Dalits evokes a feeling of pride, of collective strength-a feeling that will help participants brace themselves against their fear and dejection: 
For Dalit victims it's very difficult to talk, they're scared to go on the stage and speak; they need support... Victims are scared, not only of retaliation: a Dalit victim is used to be scared-to enter the room of any administration, on the main road, they're scared. They go to the panchayat, the court, then in Delhi, they have to talk to so many people. There is fear of retaliation too... How can you share it in public? It's very difficult for ladies especially. Sometimes they cry on the stage, the activist has to explain everything, they recall all the difficulties. ${ }^{22}$

In a very different example, a skit making fun of municipal bureaucrats and politicians, at the beginning of a public hearing devoted to monitoring the use of municipal councilors' funds, clarified the issue at stake even while it asserted the legitimacy of citizens claiming control over the allocation of public resources.

41 Such use of cultural elements supports the didactic dimension of public hearings ${ }^{23}$ another strong common point with community meetings. Thus the organizer of the jan sunwai on the implementation of the Right to Education Act explained:

We found it a little difficult to make the community understand the education system... so we needed theater ... we created some songs about schools to make the community understand more easily. We have 150 volunteers in the community who study in these schools; they made this song in form of a dialogue-very antiteachers! Songs are a vehicle of communication. Plus who is singing it, is strategic... When young persons, school girls, sing about the state of schools, the impact is different, it gives them an important connection. In education the relationship is between a child, very vulnerable, and an adult..$^{24}$

Whatever the issue at stake, public hearings are meant to highlight and clarify, in a very pedagogical way, the connection between the individual and the collective, the specific and the general, what is considered private and what is considered public, concrete cases and abstract issues, justice as an institutional process and justice as an ideal. In this regard the jury has a major role to play in moderating the exchanges during the public hearing. It is the jury's role to perform the shift from the specifics of the individual case being presented to a more collective, general (yet very concrete) discussion of what should have been done, what must be done now, and how to avoid the continuation of that victimization.

It must also be noted-this came through in many interviews-that the didactic dimension of public hearings is in play for all participants: the presentation and discussion of cases will enable the public, but also the media and even jury members and organizers, to better understand the issue at stake. An example is given by a Kolkatabased trade-unionist:

In 2004 [we worked on] evictions, displacement, we were part of a movement against eviction of slums in Calcutta, it was organized with other people, we went all over the state organizing a public hearing on this issue: we had terms of references, we set up a secretariat, a jury, we gave it a formal tinge, the panel knew what they had to do because of the terms of reference. The objective was a report about what is wrong with the government's action, we were trying to create public opinion... We wanted to get people who are interested in the issue to be more involved; lots of people came, it created awareness; we sent the report to the government and publicized it; we started in 2003, and in 2006 the whole displacement issue became major in West Bengal; we contributed to that. Also we got exposure to that issue ourselves..$^{25}$

"The prime objective is to educate the people... It changes the mind-set, especially on issues of discrimination or sexual harassment... It gives a technical understanding to case 
facilitators and activists also," said another activist who used the jan sunwai in his work with Dalit communities. ${ }^{26}$

\section{Restoring citizenship}

Like a court hearing in a trial, a public hearing is concerned with individual cases, specific facts and specific legislation; it has solemnity, it is about past injury and present redress of grievance. At the same time, like a community meeting, it has warmth and effervescence, it is concerned with the group, it can be used to inform, sensitize, and motivate, in view of a better future for the community as a whole. This essential hybridity suggests strong affinities between public hearings and the Truth commissions that have been set up in some thirty countries over the past three decades (Lefranc 2013). Such commissions, following the pioneering example of South Africa's Truth and Reconciliation Commission (1996-1998), embody the twin concepts of transitional justice and restorative justice.

According to Cole, transitional justice results from "a convergence of the human rights movement and international law" (Cole 2007) and can be defined as

a way to cope with the aftermath of systemic and large scale violations of human rights ... to grapple with the ultimate failure of traditional jurisprudence on the face of contending demands for justice, reparation, acknowledgements, mourning, healing, reconciliation, and the promulgation of public memory; [while] its attendant notion of "restorative justice" ... focuses on restoring humanity to both perpetrator and victim (Cole 2010).

There are obviously major differences between public hearings and Truth commissions. Firstly, only a minority of public hearings-i.e. those organized in the framework of an officially mandated social audit-can avail of the official status that pertains to Truth commissions; and even in that case, they exist on a more local, less central level. Secondly, public hearings may be organized around instances of massive human rights violations (for instance atrocities against Dalits or religious minorities ${ }^{27}$ ), but many of them deal with less tragic issues, such as, for example, the use of the discretionary funds allotted to elected representatives at the municipal and state levels.

In spite of these differences, I argue that there is heuristic value in comparing public hearings with Truth commissions, because such a comparison draws our attention to three defining features that are common to both dispositives, and that help understand how public hearings can-in the best of cases-"restore" citizenship in the Indian context. These features are (i) the didactic dimension of the procedure; (ii) the space it grants to victims' expression; and (iii) its emotional intensity.

47 I have already highlighted the didactic dimension of public hearings, a dimension that allows them, like Truth commissions, to at the same time "dramatize and document" (Cole 2007:170) the issue at stake.

common feature is the central position given to victims and the amplification of their voices. Indeed a major assumption of restorative justice is that "victims and their testimonies must be central while ensuring justice for gross human rights violations" (Farasat 2012); and that one of the roles of justice is to help victims "rebuild" themselves (Barbot and Dodier 2011).

In India, the role of victims is a major difference between public hearings and trials: in the former victims are not only allowed to speak, but also to express their emotions-a 
point to which I shall return. Gopal Guru, reflecting on the significance of the jan sunwai as a form of mobilization for Dalits in particular, asserts that "one of the reasons for the evolution of the jan sunwai was the judicial system in the country which by the processes and institutions it spawned rendered the victim invisible" (Guru N.d.:1).

Even though the amount of time granted to aggrieved persons to present their case is usually much shorter in public hearings than in Truth commissions (5-10 minutes as opposed to 20-30 minutes), the specific organization of public hearings is meant to encourage the expression of the victims' truth, a truth that might be stifled both by the modus operandi of Indian courts and by the fear of retaliation. Because the audience of public hearings is sympathetic to aggrieved persons, it offers them a sense of protection and increases their self-confidence, as explained by an activist:

One reason why the public hearing is working really well in India is because it gives strength to people to speak out ... because [the issue] is discussed very openly with 500 people testifying together, it prevents people to get intimidated in an individual sense. ${ }^{28}$

And one of the organizers of a public hearing on a massacre perpetrated on Dalits in Bihar told me:

Certain truths or testimonies are actually suppressed or buried; basically a people's tribunal is an attempt to have those testimonies come forward and be viewed by citizens; of course it's not a parallel court ... the idea is to establish that in fact this testimony does have weight, it should weigh with other institutions as well..$^{29}$

The third element shared by public hearings and Truth commissions-an element which was only alluded to so far-is their emotional intensity. ${ }^{30}$ Thus in South Africa it was believed that "the power of emotions generated by the narration of suffering would help a re-foundation of the "rainbow nation," writes Lefranc, who also evokes "cathartic deliberations" (Lefranc 2013:2). Catharsis has indeed been an explicit objective of Truth commissions. In the Indian context, the essential hybridity of public hearings, in-between the formality of a trial and the informality of a community meeting, has been shown to generate a specific emotional dynamics (Tawa Lama-Rewal 2015) that might be compared to catharsis. "In India, where you have large scale human rights violations, people need some kind of relief and consolation but the police, the courts, the state don't give that," said a retired judge who has been on the jury of many public hearings. ${ }^{31}$

51 A view formulated somewhat differently by an activist:

In a public hearing the community is there... and that is an opportunity for people to interact and share your tears, express your anger, your emotions ... it's very important for a person who's suffering from a long time, who's a victim of injustice. 32

Finally, Truth commissions have been described as "highly performative events" (Cole 2007:174). The notion of performance, as richly defined by Cole, proves very useful for delving deeper into the understanding of the political efficacy of public hearings:

The multifaceted meanings of "performance" ... include the following: to accomplish an act, to make a public presentation, to use embodiment as a central instrument of communication, and to simulate or represent (i.e., to "act") (Cole 2007:178)

52 Let us consider the four elements of the above definition, with regard to public hearings, in reverse order. One, performance as representation. We have already seen that public hearings have some features of a carefully prepared show, i.e. a representation in the theatrical sense of the term. There are elements of rehearsal when it comes to testifiers: as I said, the people whose case will be discussed on D-day undergo a kind of training in 
order to be able to tell their story in a brief, clear manner. There is a sense of casting in the constitution of the jury: jury members are selected with an eye to their ability to enthuse an audience; they preferably "have some star quality," ${ }^{33}$ as one of them candidly explained. The spatial organization of the interactions, as well as the nature and timing of elements of popular culture (songs etc.) also play an important role: they provide rhythm and set the tone of the meeting at key moments (the beginning and the end), but also when attention is waning or when people are overcome with emotion (Tawa LamaRewal 2015).

53 Two, performance as embodied representation. In public hearings, social issues have a body and a face, they find a human incarnation in the victim who comes and testifies. This is crucial to the capacity of public hearings to sensitize their audience-the public, jury members, administrative officers and (through the media) public opinion. Thus an expert/activist explained:

the problem with middle-class activism is the way you cushion the government and other middle-class functionaries ... government officials don't come face to face with the horror, the anger, the frustration. So that's part of the jan sunwai, to bring things face to face. ${ }^{34}$

Incidentally, here lies an important difference between jan sunwais and people's tribunals: in the latter, cases are more often presented by activists than by victims; this mediation certainly explains the fact that people's tribunals are largely devoid of the emotional intensity that characterizes jan sunwais.

Three, performance as public presentation: this brings us back to the fact, mentioned above, that awareness raising in the largest sense is a major objective of public hearings. " Jan sunwai is very effective, at least it brings the problems before the administration," said an activist who organized a jan sunwai on the Right to Education Act. ${ }^{35}$

And four, performance as action: public hearings are meant to put pressure on authorities -be it the courts, a state department or a village sarpanch. As an anti-corruption activist put it, "jan sunwai is useful to create a mahaul [atmosphere] so the government goes for negotiation, the government tries to consider your request." ${ }^{36}$

These series of affinities between public hearings and Truth Commissions suggest that public hearings offer an informal type of restorative justice; that they are a kind of truth commission with a small " $\mathrm{t}$ ": the truth that is being uncovered in these meetings is often called, less solemnly, "information," but the two terms are clearly synonymous in the context of Indian social movements post-NCPRI. ${ }^{37}$ I was told by an education activist: "In our handbill ${ }^{38}$ we said: 'we have a public hearing so that truth may prevail."' ${ }^{9}$

Indeed the notion of restorative justice is useful to understand the specific efficacy of public hearings as a form of collective action. What is restored through public hearings is sometimes, as in Truth commissions, humanity-this is the case, for instance, of public hearings on Dalit atrocities. But more often, it is citizenship, understood here as a relation between the individual and the state, but also between citizens (Jayal 2013:2) that is characterized by a series of rights and responsibilities. Public hearings help people realize that as Indian citizens they have rights, entitlements, and that it is the responsibility of state authorities to protect such rights and deliver on such entitlements. In the Indian context, marked by the "deep hostility of the government bureaucracy towards the poor" (Dreze 2002:818), public hearings are a strong tool to demand accountability (Goetz and Jenkins 2005), and thereby to build citizenship. The didactic dimension, combined with the emotional intensity of public hearings, makes them 
particularly effective for communicating the idea of citizenship. Talking about the impact of the jan sunwai on the Right to Education Act, one activist told me:

for the first time people felt the power of citizenship on that day ... before that, parents feared the [school] principal, they were scared to go to the school, [they thought] "we're uneducated people, we can't know how to speak to the principal"; it's like a myth, on the day of the jan sunwai the barriers were broken, and after the jan sunwai, lots of parents started going to the schools. ${ }^{40}$

This is one of several examples testifying to the fact that public hearings, in the best of cases, actually transform the relationships between the various types of participants. Here parents adopted a new behavior vis-à-vis school authorities; and a teacher decided to help one of the victims to find a school for her daughter. Several jan sunwais about public works organized by the MKSS in Rajasthan also ended with elected local representatives having to refund the money that they were shown to have embezzled (Jenkins and Goetz 1999)

\section{Conclusion}

Several authors have analyzed the relationship between the right to information, social audits and citizenship (Jenkins and Goetz 1999; Baviskar 2010; Webb 2010). Public hearings have been described as a particularly innovative, empowering mode of mobilization (Mander and Joshi N.d.). Indeed they demonstrate, in a very didactic manner, that people have rights while authorities have responsibilities, thus bringing a major change of perspective for the Indian poor. With public hearings, claim-making takes the form of demanding grievance redress: what is being claimed is not new laws, policies and schemes, but the proper implementation of existing laws, policies and schemes, that is, accountability in the strongest sense.

The inventiveness and grit of the MKSS, the political context of the first United Progressive Alliance government and the social resources of the NCPRI are obviously major factors in the significance of public hearings in today's India. In this paper I have explored other possible reasons why public hearings can be such a powerful, empowering form of mobilization. In order to interpret public hearings as a social performance, I have compared them with two modes of judiciary intervention that depart from the ordinarythe PIL in India, Truth commissions in other countries-and highlighted a series of affinities, both substantive and procedural, between the three dispositives. This interpretive analysis points to the deep originality of public hearings as a form of collective action, and to their political significance, insofar as they can restore citizenship -either alone, when they're most successful, or as part of a larger process that also involves the media and the courts.

There are however important constraints weighing on the capacity of public hearings to reach this achievement. Among the various types of public hearings I have discussed here, the jan sunwai is the one which best works to restore the citizenship of its participants. But the jan sunwai, as I have shown, is a very demanding form of collective action, which puts a question mark on its capacity to be replicated all over the country. In order to avoid losing its teeth in a ritualized-therefore ineffective-version of itself, the jan sunwai requires committed activists able to put in several months of work; "eminent" people ever ready to participate as jury members; and administrative officers willing to occupy the usually uncomfortable position of having to represent the authorities. 


\section{BIBLIOGRAPHY}

Alexander, Jeffrey C. 2004. "Cultural Pragmatics: Social Performance between Ritual and Strategy." Sociological Theory 22(4):527-73.

Anon. 2011. "Most Complaints under RTE Act Relate to Dirty Toilets." The Hindu, April 22. Retrieved December 22, 2017 (http://www.thehindu.com/features/education/issues/Mostcomplaints-under-RTE-Act-relate-to-dirty-toilets/article14692910.ece).

Barbot, Janine and Nicolas Dodier. 2011. "De la Douleur au droit. Ethnographie des plaidoiries lors de l'audience pénale du procès de l'hormone de croissance contaminée." Pp. 289-322 in Du Civil au politique. Ethnographies du vivre ensemble, edited by D. Cefaï, M. Berger and C. Gayet-Viaud. Bruxelles: Peter Lang.

Baviskar, Amita. 2010. “Winning the Right to Information in India: Is Knowledge Power?” Pp. 129 -50 in Citizen Action and National Policy: Making Change Happen, edited by J. Gaventa and R. McGee. London/New York: Zed Books.

Berti, Daniela. 2011. "Courts of Law and Legal Practice." Pp. 355-70 in A Companion to the Anthropology of India, edited by I. Clark-Decès. London: Wiley-Blackwell.

Byatnal, Amruta. 2012. "Apathy, the Disease.“ The Hindu, June 24. Retrieved December 22, 2017 ( http://www.thehindu.com/news/national/other-states/apathy-the-disease/article3562996.ece). Chowdhury, Sudeshna. 2011. "The Case for Gender." Thirunangainews, December 23. Retrieved December 22, 2017 (http://thirunangainews.blogspot.com/2011/12/).

Cole, Catherine M. 2007. "Performance, Transitional Justice, and the Law: South Africa's Truth and Reconciliation Commission.” Theatre Journal 59(2):167-87.

Cole, Catherine M. 2010. Performing South Africa's Truth Commission: Stages of Transition. Minneapolis: Indiana University Press.

Dreze, Jean. 2002. “On Research and Action.” Economic and Political Weekly 37(9):817-19.

Dreze, Jean. N.d. "Right to Food: From the Courts to the Streets." Retrieved September 15, 2014 ( http://www.sccommissioners.org/Starvation/Articles/drezecourts.pdf).

Farasat, Warisha. 2012. "Pushing boundaries for justice." The Hindu, October 18.

Foucault, Michel. 1980. Power/Knowledge: Selected Interviews and Other Writings 1972-1977. New York: Harvester Wheatsheaf.

Ghosh, Arjun. 2012. A History of the Jana Natya Manch: Plays for the People. SAGE Publications India. Goetz, Anne-Marie and Rob Jenkins. 2005. Reinventing Accountability: Making Democracy Work for the Poor. London: Palgrave Macmillan.

Guru, Gopal. N.d. “Jan Sunwai: A New Instrument of Democracy in India." State of Democracy in South Asia Study. Retrieved September 16, 2014 (http://www.democracy-asia.org/ casestudies_studies_gopal_guru_p2.htm).

Hirschl, Ran. 2006. "The New Constitutionalism and the Judicialization of Pure Politics Worldwide." Fordham Law Review 75(2):721-53. 
Iqbal, Mohammed. 2015. "Workers Voice Grievances at Jun Sunwai.“ The Hindu, April 25. Retrieved December 22, 2017 (http://www.thehindu.com/news/cities/Delhi/workers-voicegrievances-at-jun-sunwai/article7139973.ece).

Jayal, Niraja Gopal. 2013. Citizenship and its Discontents: An Indian History. Cambridge/London: Harvard University Press.

Jenkins, Rob. 2010. "Non-governmental Organizations." Pp. 423-40 in The Oxford Companion to Politics in India, edited by N.G. Jayal and P.B. Mehta. Delhi: Oxford University Press.

Jenkins, Rob and Anne Marie Goetz. 1999. "Accounts and Accountability: Theoretical Implications of the Right-to-Information Movement in India.” Third World Quarterly 20(3):603-22.

Kohli, Kanchi and Manju Menon. 2012. "The Nature of Green Justice.” Economic and Political Weekly XLVII(15):19-22.

Lefranc, Sandrine. 2013. "Un Tribunal des larmes. La Commission sud-africaine "Vérité et Réconciliation." La vie des idées October.

Mander, Harsh and Abha Joshi. N.d. THE MOVEMENT FOR RIGHT TO INFORMATION IN INDIA: People's Power for the Control of Corruption. The Human Rights Initiative. Retrieved December 19, 2017 ( http://www.humanrightsinitiative.org/programs/ai/rti/india/articles/The\%20Movement\%20for \%20RTI\%20in\%20India.pdf).

Mazdoor Kisan Shakti Sangathan. 2017. Retrieved December 23, 2017 (http://mkssindia.org/). National People's Tribunal on Kandhamal. 2011. Waiting for Justice: A Report. New Delhi.

Quéré, Louis. 2003. "Le Public comme forme et comme modalité d'expérience." Pp. 113-34 in Les Sens du public. Publics politiques, publics médiatiques, edited by D. Cefaï and D. Pasquier. Paris: PUF. Rajagopal, Arvind. 2016. “On Media and Politics in India: An Interview with Paranjoy Guha Thakurta.” South Asia: Journal of South Asian Studies 0(0):1-16.

Ramanathan, Usha. 2002. "Book Review of Judicial Activism in India: Transgressing Borders and Enforcing Limits, by S.P. Sathe, Delhi, Oxford University Press, 2002.” Seminar (512).

Sen, Sarbani. 2012a. "L'Intérêt public en Inde. Contestation et confrontation devant la Cour suprême." Diogène (339-340):37-65.

Sen, Sarbani. 2012b. Public Interest Litigation in India: Implications for Law and Development. Kolkata. Sharma, Prashant. 2014. Democracy and Transparency in the Indian State. London: Routledge.

Shivakumar, Girija. 2014. "Pension Parishad Organizes Jan Sunwai in Delhi.“ The Hindu, January 17. Retrieved December 22, 2017 (http://www.thehindu.com/news/cities/Delhi/pensionparishad-organizes-jan-sunwai-in-delhi/article5586925.ece).

Simm, Gabrielle and Andrew Byrnes. 2014. “International Peoples' Tribunals in Asia: Political Theatre, Juridical Farce, or Meaningful Intervention?” Asian Journal of International Law 4(1):10324.

Sircar, Oishik. 2012. "Spectacles of Emancipation: Reading Rights Differently in India's Legal Discourse.” Osgoode Hall Law Journal 49(3):527-73.

Sundar, Nandini. 2011. "The Rule of Law and the Rule of Property: Law-struggles and the Neoliberal State in India." Pp. 175-93 in The State in India after Liberalization, edited by A. Gupta and K. Sivaramakrishnan. New York: Routledge. 
Tawa Lama-Rewal, Stéphanie. 2015. "Les Audiences publiques en Inde. Mobilisation de la rue et enrôlement des experts." Pp 115-25 in Emotions et expertises. Les modes de coordination des actions collectives, edited by C. Traïni. Rennes: Presses universitaires de Rennes.

Traïni, Christophe. 2015. Emotions et expertises. Les modes de coordination des actions collectives. Rennes: PU Rennes.

The Hindu. 2005. "Jan Sunwai Exposes Total Bias against Dalits.” The Hindu, September 9. Retrieved December 22, 2017 (http://www.thehindu.com/2005/09/09/ stories/2005090913410500.htm).

The Hindu. 2010. "'State of Malnutrition in Delhi Worse than Sub-Sahara." The Hindu, May 7. Retrieved December 22, 2017 (http://www.thehindu.com/news/cities/Delhi/lsquoState-ofmalnutrition-in-Delhi-worse-than-sub-Sahara/article16298918.ece).

Warner, Michael. 2002. "Publics and Counterpublics." Public Culture 14(1):49-90.

Webb, Martin. 2010. "Success Stories: Rhetoric, Authenticity, and the Right to Information Movement in North India." Contemporary South Asia 18(3):293-304.

\section{NOTES}

1. Part of the fieldwork for this paper was conducted with the support of the collaborative research project on "Emotions and Political Mobilisations in the Indian Subcontinent," co-funded by the "Emergence(s)" program of the City of Paris, to whom I express my gratitude. I also want to express my sincere thanks to Martin Aranguren, Amélie Blom, Rob Jenkins, Christophe Traïni, and to the participants of the "JustIndia" seminar for their comments on earlier versions of this text. Finally I am very grateful to the three anonymous reviewers, for their stimulating comments and suggestions.

2. Another phrase often used to describe the new relationship between representative institutions and the judiciary is the "judicialization of politics" (Hirschl 2006).

3. Following Traïni, I call "experts" those people who (implicitly or explicitly) justify the relevance of their viewpoint by the fact that they possess a specific, socially recognized, knowledge of the issue at stake (Traïni 2015:20).

4. The word "public" refers here primarily to a quality of the hearing, which is organized in a manner that is open, visible and audible by all; but it also strongly evokes an entity-the public as a "social group conscious of its collective identity" (Quéré 2003:116). We will see later that the public of public hearings is actually often a "counterpublic" (Warner 2002) insofar as it is made of subalterns whose discourse takes a form that is unusual in large meetings, namely personal testimonies.

5. The notion of "CSO" encompasses a large number of organizations that vary in their legal status, material resources and proximity to the people they're working with. Thus CSOs can be "non-governmental organizations" (NGOs), "community-based organizations" (CBOs) or "grassroots organizations." I prefer to use the generic notion of CSO because (i) these organizations often evolve from one subtype to another (for instance from CBO to NGO) and (ii) each subtype carries a series of connotations, positive or negative, that I don't want to consider here (see Jenkins 2010). For instance the "grassroots" nature claimed by the MKSS is important to the political efficacy of its discourse; yet it is also debatable, as shown by Prashant Sharma (Sharma 2014).

6. By "dispositive" I mean, following Foucault, a coherent if heterogeneous set of institutions, discourses and practices (see Foucault 1980). 
7. For a rich analysis of the MKSS' engagement with the right to information, see Jenkins and Goetz (1999); also Mander and Joshi (N.d.).

8. The National Advisory Council was set up in 2004 to provide advice to the Prime Minister regarding the implementation of the Common Minimum Program of the UPA; it was chaired by the president of the Congress party, Sonia Gandhi.

9. For a detailed analysis of the network of individuals and organizations that supported the NCPRI, see Sharma (2014).

10. This form is not specific to India. For a comparative analysis of the nature and political significance of people's tribunals (of which there are more than eighty today), including a case study on the Independent people's tribunal on the World Bank in India held in 2007, see Simm and Byrnes (2014)

11. Interview, CSO activist, Delhi, 09/03/2012.

12. Research on the implementation of the Environmental Impact Assessment Notification has indeed shed light on the many ways in which the material organization of public hearings (the choice of a date and a location, the mode of publicization of the event etc.) can empty it of any serious possibility to contest the project at stake.

13. Interview, CSO activist, Delhi, 17/12/2013.

14. The court evoked by public hearings, as we will see later, is in large part imagined: in real Indian courts there have been no juries since 1960.

15. Therefore, the administrative officers who participate as representatives of the concerned departments are often boxed, in the role of the accused.

16. Interview, CSO activist, Delhi, 24/12/2012

17. Those media that report with some regularity on jan sunwais, however, are a minority; they're mostly newspapers and magazines, both national and regional, that are sympathetic to a Leftist perspective on Indian politics, such as the Hindu, Frontline, or Civil Society. See Rajagopal (2016)

18. Jean Dreze refines this point in his evocation of the Right to Food campaign-which used jan sunwais along with other forms of mobilization: "The Supreme Court orders are extremely useful in strengthening the bargaining power of all those who are working for the realization of the right to food in India. But it would clearly be naïve to expect these orders to be implemented without further public pressure" (Dreze N.d.)

19. Interview, CPI-ML activist, Delhi, 24/02/2014.

20. I thank Rob Jenkins for pointing this out to me.

21. The notion of community is linked to the role of CSOs in the organization of public hearings; CSOs generally refer to the population they work with as "community"-although this might mean very different types of groups: the inhabitants of a slum, or Dalits, or children...

22. Interview, NGO program coordinator, Delhi, 2/03/2012

23. This didactic dimension draws on the tradition of activist street theater as represented, for instance, by the Delhi-based Jana Natya Manch (Ghosh 2012)

24. Interview, CSO activist, Delhi, 24/12/2012

25. Interview, trade unionist, Delhi, $24 / 12 / 2013$

26. Interview, CSO activist, 02/11/2011

27. See National People's Tribunal on Kandhamal (2011).

28. Interview, CSO activist, Delhi, 03/01/2013

29. Interview, CPI-ML activist, Delhi, 24/02/2014

30. Here lies also a major contrast between PIL and public hearings: in India a Chief Justice cautioned that "the court had to avoid emotional appeal and rely on legal principle" (Sen 2012a:15).

31. Interview, retired judge, Delhi, 16/12/2013.

32. Interview, CSO/party activist, Delhi, 22/02/2014

33. Interview, expert/activist, Delhi, 06/03/ 2012. 
34. Interview, expert/activist, Delhi, 06/03/ 2012

35. Interview CSO activist, Delhi, 27/10/2011.

36. Interview CSO activist, Delhi, 18/10/2011.

37. In 2005, an issue of the Indian journal Seminar devoted to the right to information was entitled "Speaking Truth to Power" (http://www.india-seminar.com/semframe.html)

38. The handbill referred to was distributed to villagers and authorities to inform them about the organization of a public hearing.

39. Interview CSO activist, Delhi, 04/03/2012.

40. Interview, CSO activist, Delhi, 24/12/2012

\section{ABSTRACTS}

Since the late 1990s, major claims addressed to the Indian state by, or on behalf of, the underprivileged, have been formulated in terms of rights (right to work, to food, etc.). Collective action increasingly addresses the courts as much as governments or legislative assemblies. This paper aims to show, through an analysis of public hearings (jan sunwai in Hindi), that such "legalism" of Indian progressive social movements is at work not only in the language, but also in the form of mobilizations. In order to interpret public hearings as social performance, I compare them with two modes of judiciary intervention that depart from the ordinary-the PIL in India, Truth commissions in other countries-and thereby highlight a series of affinities, both substantive and procedural, between the three dispositives. This interpretive analysis points at the deep originality of public hearings as a form of collective action, and at their political significance insofar as they can, in the best of cases, restore citizenship.

INDEX

Keywords: PIL, judicial activism, Right to Information, social performance, public hearing, restorative justice, people's tribunal, jan sunwai, citizenship, India

\section{AUTHOR}

\section{STÉPHANIE TAWA LAMA-REWAL}

Research Fellow, French National Center for Scientific Research 